\title{
Vitamin C Binds to SARS Coronavirus-2 Main Protease Essential for Viral Replication
}

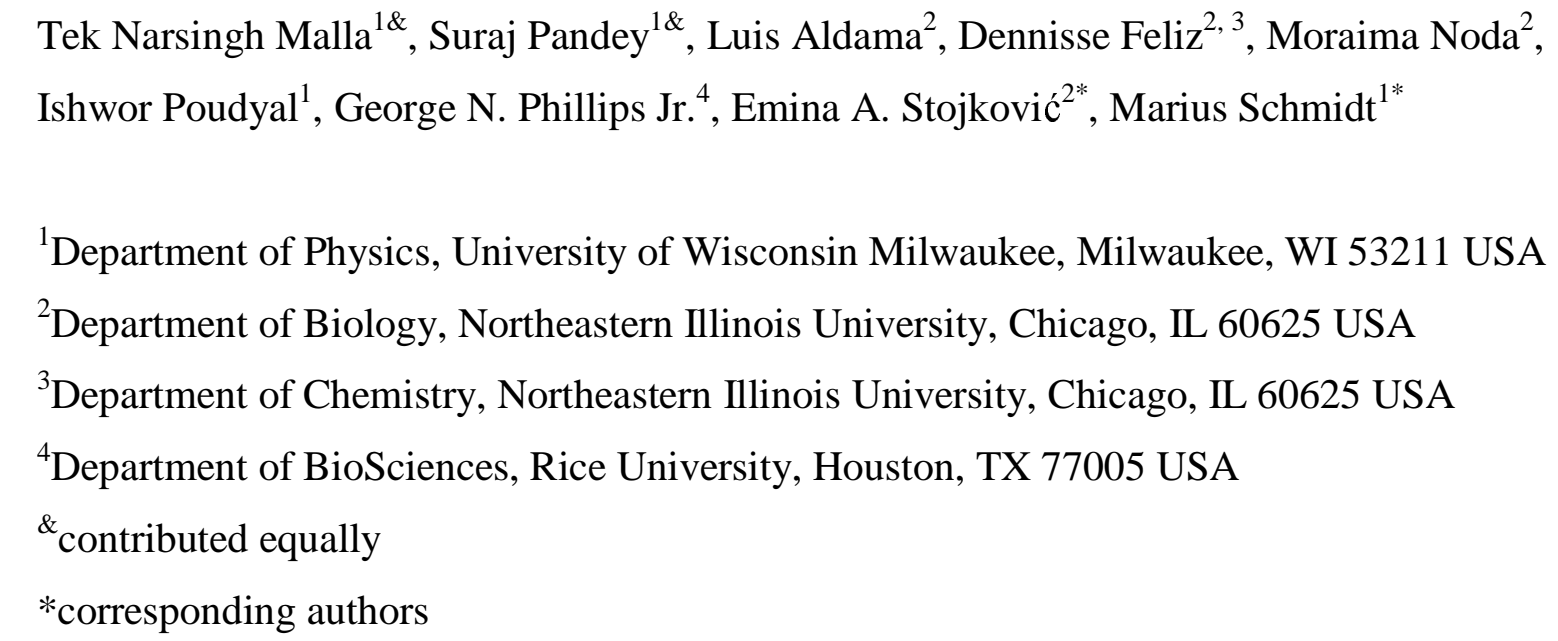

\section{Abstract}

There is an urgent need for anti-viral agents that treat and/or prevent Covid-19 caused by SARSCoronavirus (CoV-2) infections. The replication of the SARS CoV-2 is dependent on the activity of two cysteine proteases, a papain-like protease, PL-pro, and the 3C-like protease known as main protease Mpro or 3CLpro. The shortest and the safest path to clinical use is the repurposing of drugs with binding affinity to PLpro or 3CLpro that have an established safety profile in humans. Several studies have reported crystal structures of SARS-CoV-2 main protease in complex with FDA approved drugs such as those used in treatment of hepatitis C. Here, we report the crystal structure of 3CLpro in complex Vitamin C (L-ascorbate) bound to the protein's active site at 2.5 Ångstrom resolution. The crystal structure of the Vitamin C 3CLpro complex may aid future studies on the effect of Vitamin $\mathrm{C}$ not only on the coronavirus main protease but on related proteases of other infectious viruses. 


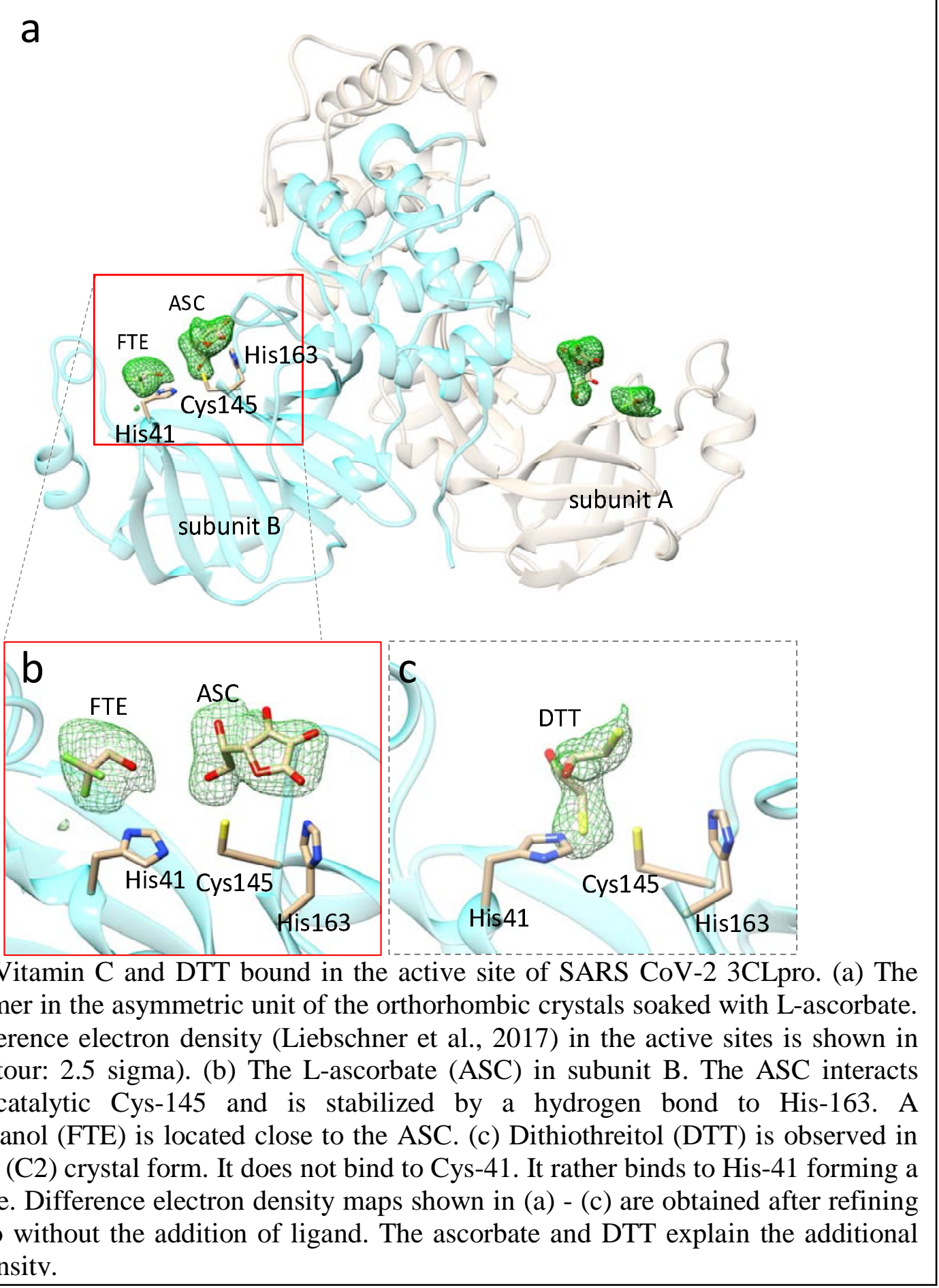

Figure 1. Vitamin C and DTT bound in the active site of SARS CoV-2 3CLpro. (a) The 3CLpro dimer in the asymmetric unit of the orthorhombic crystals soaked with L-ascorbate. Polder difference electron density (Liebschner et al., 2017) in the active sites is shown in green (contour: 2.5 sigma). (b) The L-ascorbate (ASC) in subunit B. The ASC interacts with the catalytic Cys-145 and is stabilized by a hydrogen bond to His-163. A trifluoroethanol (FTE) is located close to the ASC. (c) Dithiothreitol (DTT) is observed in monoclinic (C2) crystal form. It does not bind to Cys-41. It rather binds to His-41 forming a sulfenamide. Difference electron density maps shown in (a) - (c) are obtained after refining the 3CLpro without the addition of ligand. The ascorbate and DTT explain the additional electron density.

31 coronavirus 2, has paralyzed public life globally. It has resulted in excess of 500,000 deaths in

32 the US alone as of April 2021. Although potent vaccines are now available, they are optional, not 
tested in children and potentially not as effective against new viral mutant variants emerging world-wide (LITER). The need for an effective inexpensive treatment and prevention of Covid19 still exists as large number of infections with potentially severe or lethal outcomes are still reported daily. SARS CoV-2 is a large, enveloped single-stranded RNA betacoronavirus (Cui et al., 2019). The viral RNA encodes two open reading frames that, generates two polyproteins ppla and pplab8. The polyproteins are processed by two viral cysteine proteases: a papain-like protease (PLpro) and a 3C-like protease, also referred to as the main protease (Mpro) or 3CLpro, that cleave multiple sites to release non-structural proteins (nsp1-16). These non-structural proteins form the replicase complex responsible for replication and transcription of the viral genome and have led to 3CLpro and PLpro being the primary targets for antiviral drug development. The 3CLpro is a chymotrypsin-like cysteine protease with a Cys/His dyad in the active site (Fig. 1a). The $3 \mathrm{C}$ refers to region $3 \mathrm{C}$ in the genome of the picornaviridae family, where a similar protease is found (Ramajayam et al., 2011). In coronaviruses, the 3CLpro is located in the non-structural protein (NSP) 5 coding region of the virus RNA genome (Wu et al., 47 2020).

High throughput structure based drug discovery experiments on 3CL-pro were recently conducted by large groups of scientists at synchrotrons such as Petra III (Gunther et al., 2021),

51 Diamond (Douangamath et al., 2020) and NSLS-II (to be published) among others. This

52 approach was also rapidly deployed after the 2002 SARS-CoV-1 outbreak, with earlier work by

53 the Hilgenfeld group on Mpro (3CLpro) of coronarviruses leading to crystal structures of SARS-

54 CoV-2 Mpro and inhibitor complexes (Zhang, Lin, Kusov, et al., 2020; Zhang, Lin, Sun, et al., 55 2020). Active sites of coronavirus Mpro are well conserved and those of enteroviruses (3Cpro) 56 are functionally similar: thus, providing an excellent opportunity to develop broad-spectrum 57 antivirals with structural biology approach. However, the most inhibitors investigated so far are 58 marginally water soluble. They have to be added to the crystals in an organic solvent, or they can 59 be co-crystallized. Their relative scarcity, potential toxicity and unspecificity, and a potentially 60 expensive price tag prevents their wide-spread use. Inexpensive, water soluble, and readily 61 available drugs to combat Covid-19 are urgently required. 
63 Vitamin $\mathrm{C}$ has been shown to have antiviral activity for more than half a century, including work 64 of the two-times Nobel Laureate Linus Pauling (Pauling, 1970). Vitamin C is a six-carbon 65 compound (Scheme 1) and a potent antioxidant. It is available in synthetic form and found 66 naturally in Indian gooseberry, citrus fruits and green leafy vegetables. The revival of interest in 67 Vitamin $\mathrm{C}$ therapy for acute inflammatory disorders, grounded in sound biological rationale, 68 follows decades of research. Emerging literature suggests that Vitamin C may also play an 69 adjunctive role in the treatment of a variety of viral infections (Colunga Biancatelli et al., 2020; 70 Fowler lii et al., 2017). A number of observers including Linus Pauling have suggested in the 71 past that Vitamin C in high dosages is directly virucidal (Furuya et al., 2008; Harakeh et al., 72 1990; Klein, 1945; Pauling, 1970). This assumption was based on in vitro studies, where very 73 high doses of Vitamin C, in the presence of free copper and/or iron, has virucidal activity, 74 presumably through the generation of hydrogen peroxide and other radical species (Furuya et al., 75 2008; Klein, 1945).

76

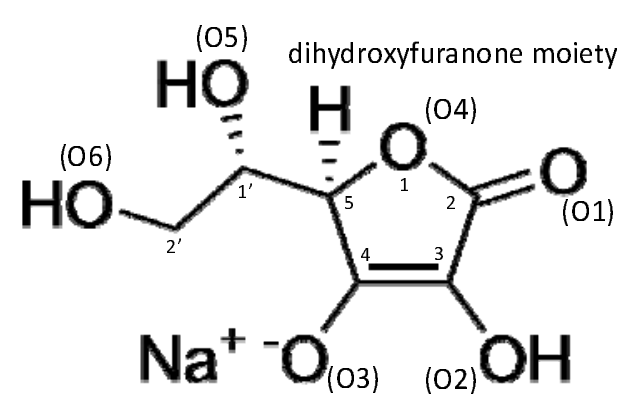

Scheme 1. The chemical structure of sodium L-ascorbate, sodium 5-[(1S)-1,2dihydroxyethyl]-3-hydroxy-4-oxo-furan2-olate. The crystallographic annotation of atoms is shown in brackets for oxygens that can be involved in hridmoran honds
A recent clinical study of injecting high doses of vitamin-C (> $20 \mathrm{~g})$ intravenously to combat Covid-19 yielded promising results (Zhao et al., 2021). In another study $8 \mathrm{~g}$ of Vitamin $\mathrm{C}$ was administered orally over three meals together with zinc (Thomas et al., 2021). The results were inconclusive although a positive trend is apparent. So far, it could not be demonstrated that Vitamin $\mathrm{C}$ is directly virucidal against Covid-19 in vivo.

In order to investigate the binding of Vitamin-C 88 directly to the CoV-2 3CLpro, we co-crystallized CoV-2 3CLpro with low concentrations (5 $89 \mathrm{mmol} / \mathrm{L}$ ) of L-ascorbate and soaked these crystals before freezing for $3 \mathrm{~min}$ in $120 \mathrm{mmol} / \mathrm{L}$ 90 ascorbate (Supplementary Material). Difference electron density that can be assigned to 91 ascorbate appears in the active sites near Cys-145 and His-163 of both subunits (Fig. 1). The L92 ascorbates only weakly interact with Cys-145 (between $3 \AA$ and $3.7 \AA$ to the sulfur, Tab. 1) but 93 form a tight hydrogen bonding network with Asn-142, Gly-143(N), His-163 and Gln-166 (Fig. 
94 S1 and Tab. 1). In addition to the L-ascorbate electron density, an additional density feature is 95 present in the active site. The pillow-like electron density (Fig. 1 b) is interpreted with a 96 trifluoroethanol (FTE) that has been provided as an additive to the crystallization buffer. The 97 interaction of the FTE with the nearby L-ascorbate is weak as the closest distance is larger than 4

$98 \AA$ (Tab. 1). Fig. 2 compares the L-ascorbate position to the position of compound $13 \mathrm{~b}$ in the 99 active site of the 3CLpro. Compound $13 \mathrm{~b}$ is a potent inhibitor of the 3CLpro (Zhang, Lin, Kusov, 100 et al., 2020). The positions of the two compound 13b oxygens O40 and O41 in the 3CLpro are 101 close to the C2' oxygen of the ascorbate (Fig. 2 a). The dihydroxyfuranone ring (Scheme 1) of 102 the ascorbate occupies a similar position as the moiety P1 of compound 13b (Fig. 2 a). The FTE 103 oxygen position is reflected by a structural water found in the compound 13b complexed 3CLpro 104 structure. 3CLpro can also be crystallized in the presence of dithiotreitol (DTT) (Zhang, Lin, 105 Sun, et al., 2020). DTT binds with one of its sulfurs between the Cys-145 and His-41 (Fig. 1 c). 106 As the distance to the His- $41 \mathrm{~N}_{\mathrm{e}}$ is substantially shorter $(1.5 \AA)$ than the one to the Cys-145 107 sulfur $(2.3 \AA)$, the DTT forms a sufenamide with His-41 which is a critical amino acid for the 108 catalytic mechanism of the 3CLpro. 


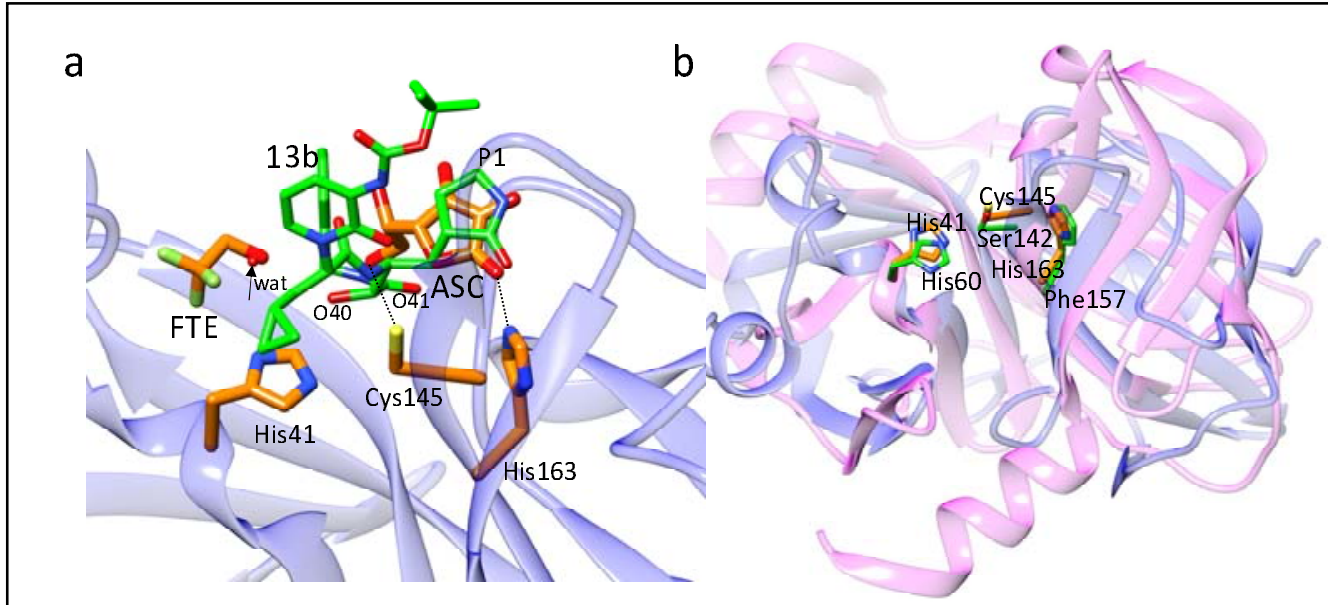

Figure 2. Structural comparisons. (a) Comparison of ligands in the active site of CoV-2 3CLpro. The position of the L-ascorbate molecule relative to compound $13 \mathrm{~b}$ in 3CLpro as determined by Zhang et al., 2020. The positions of the C2'-oxygens is close to the two compound 13b oxygens $\mathrm{O} 40$ and $\mathrm{O} 41$ (marked), and the dihydroxyfuranone-ring of ASC coincides with the P1 moiety of compound $13 \mathrm{~b}$. The arrow points to a water molecule found in the structure of 3CLpro complexed with compound 13b. This position is occupied by the FTE oxygen. (b) Overlay of the N-terminal domain of CoV2 3CLpro (blue ribbon, from residues 8 to 181) on the Hepatitis-C virus (HCV) serine protease (magenta ribbon). Active site residues are shown (orange for the 3CLpro, and green for the HCV protease). The active sites of both proteins are very similar. The positions of the catalytically active Cys145/Ser142 and His41/His60 are essentially identical. His163 in CoV-2 3CLpro is replaced by the structurally similar Phe157 in the HCV protease.

110 A search for ascorbate in the protein data bank yields 645 protein structures with only 40 111 structures that have a bound ascorbate. None of the 40 structures are viral proteins. To our 112 knowledge, this is the first structure of a viral protein with ascorbate bound in the active site. The 113 CoV-2 3CLpro has homologues in many other viruses different from coronavirus. As mentioned 114 above, a similar (3C) protease can be found in picornaviruses (Ramajayam et al., 2011). 115 Members of the picornaviridae family cause diseases such as polio (poliovirus), 116 encephalomeningitis (encephalomyocarditis virus) and the common cold (rhinovirus) (Sharma \& 117 Gupta, 2017). Moreover, the structure of the N-terminal domain of the CoV-2 3CLpro, as well as 118 that of its active site is very similar to the structure of the hepatitis-C virus (HCV) protease (Fig. 119 2), except that the HCV protease is a serine protease. However, even the HCV protease Ser-142 
120 oxygen position is essentially identical to that of the Cys-145 sulfur in the 3CLpro. The binding

121 of Vitamin $\mathrm{C}$ to the $\mathrm{CoV}-2$ 3CLpro might point to reasons why Vitamin $\mathrm{C}$ could be beneficial for

122 the treatment of coronavirus caused diseases such as SARS and middle east respiratory

123 syndrome (MERS) who have structurally similar 3CLpros (Hilgenfeld, 2014; Zhang, Lin, Sun, et

124 al., 2020). Moreover, Vitamin C might also bind to proteases of other viruses, and assists in the

125 treatment of diseases mentioned above and others such as AIDS (Harakeh et al., 1990), herpes

126 (Furuya et al., 2008; Hoog et al., 1997), rhinovirus induced respiratory distress syndrome

127 (Fowler lii et al., 2017) and even rabies (Banic, 1975).

The available inhibition test (the 'Untagged (SARS-CoV-2) Assay Kit', BPS Biosciences)

130 cannot be used to determine an inhibitory effect of L-ascorbate as the ascorbate quenches the

131 fluorescence of the enzymatically produced product at higher concentrations and inhibition tests

132 are inconclusive. Since ascorbate is detected in the crystal structure, it may well be that

133 inhibition of proteases with Vitamin C, or perhaps with one of its derivates (Mescic Macan et al.,

134 2019) that may even bind directly to the catalytically important Cys-145, becomes an important

135 factor in the treatment of Covid-19 cases and maybe other virus caused infections (Colunga

136 Biancatelli et al., 2020). Further investigations are necessary. 
139 Table 1. Comparison ligand interactions with conserved amino acids in the active site of 140 subunits A and B. Designated atoms of amino acids in subunits A and B and ascorbate ligands 141 that interact are labelled according to annotations in the refined structure (see also Scheme 1).

\begin{tabular}{|l|l|l|}
\hline \multicolumn{3}{|c|}{ 3CLpro / Ascorbate } \\
\hline & $\begin{array}{l}\text { Distances }[\AA] \\
\text { Subunit A }\end{array}$ & $\begin{array}{l}\text { Distances }[\AA] \\
\text { Subunit B }\end{array}$ \\
\hline Asn142-NOD2 / O5 & 2.4 & 2.4 \\
\hline Asn 142-NOD2 / O3 & 3.2 & 2.6 \\
\hline Cys145-SG / O6 & 3.0 & 3.1 \\
\hline Cys145-SG/ O4 & 3.7 & 3.4 \\
\hline His163-NE2 / O1 & 3.3 & 2.4 \\
\hline His 163-NE2/O4 & 3.7 & 3.9 \\
\hline Glu166-OE2 / O2 & 3.0 & 3.0 \\
\hline Gly143-N / O6 & 2.9 & 3.1 \\
\hline \multicolumn{3}{|l|}{ 3CLpro / Trifluoroethanol (FTE) } \\
\hline His41-ND / F* & 3.0 & 2.9 \\
\hline His41-O / F* & 2.8 & 3.2 \\
\hline CYS44-O / F* & 3.0 & 2.9 \\
\hline Ser 46-OG / O & 3.2 & 4.9 \\
\hline ASC-O6 / O** & 4.7 & 4.6 \\
\hline \multicolumn{2}{|c|}{ 3CLpro / Dithiothreitol (DTT) } \\
\hline His41-NE2 / S4 & 1.4 & n.a.*** \\
\hline Cys145-SG / S4 & 2.6 & -- \\
\hline H2O111-O / S1 & 2.6 & --- \\
\hline
\end{tabular}
*shortest to any of the three flour atoms ** shortest FTE to Ascorbate distance 


\section{Supplementary Material}

Expression. The CoV-2 3CLpro sequence was synthetized (GenScript) for optimized expression in E. coli according to sequence information published previously(Zhang, Lin, Sun, et al., 2020).

152 In short, the N-terminus of 3CLpro is fused to glutathione-S-transferase (GST). It further has a 6-

153 His tag at the c-terminus. The N-terminal GST will be autocatalytically cleaved off after 154 expression due to an engineered 3CLpro cleavage sequence. Although the His tag can be cleaved 155 off by a PreScission protease, the tag did not interfere with crystallization and consequently was 156 left on. Overexpression and protein purification protocols were modified from previous reports. 157 E. coli were grown to $0.8 \mathrm{OD}_{600}$ at $37^{\circ}$ in terrific broth. Expression was induced by $1 \mathrm{mmol} / \mathrm{L}$ 158 IPTG at $25^{\circ} \mathrm{C}$. After $3 \mathrm{~h}$ of expression, the culture was induced a second time ( $1 \mathrm{mmol} / \mathrm{L}$ IPTG), 159 and shaken overnight at $20^{\circ} \mathrm{C}$. The yield is about $80 \mathrm{mg}$ for a $6 \mathrm{~L}$ culture. Cells were 160 resuspended in lysis buffer (20mM Tris Base, $150 \mathrm{mmol} / \mathrm{L} \mathrm{NaCl}, \mathrm{pH}$ 7.8.). After lysis of the 161 bacterial cells, debris was centrifuged at 50,000 g for 1 hour. The lysate was let stand at room 162 temperature for $3 \mathrm{~h}$ (overnight is also possible). After this, the lysate was pumped through a 163 column containing $15 \mathrm{~mL}$ of Talon Cobalt resin (TAKARA). The resin was washed without 164 using imidazole using a wash cycle consisting of low salt $(20 \mathrm{mmol} / \mathrm{L}$ Tris Base, $50 \mathrm{mmol} / \mathrm{L}$ $165 \mathrm{NaCl}, \mathrm{pH} 7.8)$, high salt $(20 \mathrm{mmol} / \mathrm{L}$ Tris Base, $1 \mathrm{~mol} / \mathrm{L} \mathrm{NaCl}, \mathrm{pH} 7.8)$ and low salt (as above) 166 solutions (about 20 column volumes each). After the wash cycle was completed, the column was 167 let stand for an additional $2 \mathrm{~h}$ at room temperature followed by another wash cycle. The final 168 product was eluted by $300 \mathrm{mmol} / \mathrm{L}$ imidazole. Buffer exchange was achieved at $4{ }^{\circ} \mathrm{C}$ by either 169 by 3 times spin-concentration and re-dilution with $20 \mathrm{mmol} / \mathrm{L}$ Tris base, $150 \mathrm{mmol} / \mathrm{L} \mathrm{NaCl}, 25$ $170 \mathrm{mmol} / \mathrm{L} \mathrm{Na}$-ascorbate, or by dialyzing immediately in $20 \mathrm{mmol} / \mathrm{L}$ Tris base, $150 \mathrm{mmol} / \mathrm{L} \mathrm{NaCl}$, $1710.1 \mathrm{mmol} / \mathrm{L}$ dithiotreitol (DTT), $\mathrm{pH}$ 7.8. The preparations were concentrated to a 3CLpro 172 concentration of $20 \mathrm{mg} / \mathrm{mL}$. Since the 6-His tag was not cleaved off, this one step purification 173 protocol required only $\sim 10 \mathrm{~h}$ from cell lysis to the pure 3CLpro product. The product is within 174 1.7 Da of the theoretical molecular weight as determined by mass spectroscopy.

176 Crystallization. The concentrated 3CLpro containing DTT was diluted to $4 \mathrm{mg} / \mathrm{mL}$. $100 \mu \mathrm{L}$ of 177 the diluted 3CLpro was mixed (1:1) in batch mode with the same amount of $25 \%$ PEG 3350, 178 Bis-Tris $100 \mathrm{mmol} / \mathrm{L}, \mathrm{pH}$ 6.5. Rectangular shaped crystals with dimensions of about $200 \times 30$ x 
$17930 \mu^{3}$ were obtained. Crystals of the ascorbate containing 3CLpro were obtained by the 180 hanging drop method by mixing $2 \mu \mathrm{L}$ of $30 \mathrm{mg} / \mathrm{mL}$ protease with an equal amount of a reservoir 181 solution containing $15 \%$ PEG 3350, 5 mmol/L ascorbate, and trifluoroethanol (FTE) (4\%) as an 182 additive. Crystals formed long thin needles after 3 -day incubation at $16^{\circ} \mathrm{C}$. Crystals were soaked 183 in mother liquor containing an addition of $120 \mathrm{mmol} / \mathrm{L}$ ascorbate and $20 \%$ glycerol as a 184 cryoprotectant for 3 min before freezing.

Data Collection and Structure determination. The crystals were mounted in Mitegen micro-loops (30 - 50 $\mu \mathrm{m}$ ) and directly frozen in pucks suspended in liquid nitrogen for automated (robotic) data collection. The dewar with the pucks were provided to the Advanced Photon Source, Argonne National Lab, Lemont, IL, for robotic data collection at Sector-19 (Structural Biology Center, SBC, beamline 19-ID-D). Data collection was fully remote due to restriction of the COVID-19 pandemic. Dataset to $2.2 \AA$ and $2.5 \AA$, respectively, were collected $\left(0.5^{\circ}\right.$ rotation and $0.8 \mathrm{~s}$ exposure per detector readout for a total of $180^{\circ}$ ) on the 3CLpro with DTT and L-ascorbate, respectively. Data was processed with HKL3000 (Minor et al., 2006). Data statistics in shown in Tab. 1. The spacegroup of the DTT containing crystals was C2. For refinement, the 3CLpro structure with pdb access code 6Y2E (Zhang, Lin, Sun, et al., 2020) was used as initial model. Molecular replacement was not necessary as the model fits immediately. Refinement was achieved using refmac (Murshudov et al., 2011) (version 5.8.0238). The electron density of the DTT becomes apparent by a difference electron density feature in between His-41 and Cys-145 (Fig. 1 c). With L-ascorbate and FTE in the buffer, the spacegroup becomes P $2{ }_{1} 2_{1} 2_{1}$ with cell constants not found so far for the CoV-2 3CLpro. Molecular replacement was performed by Phaser (Oeffner et al., 2013) version 2.8.2 using pdb-entry 6XQT (Kneller et al., 2020) as a search model. After refinement of the molecular replacement solution, difference electron density of both, the L-ascorbate and the FTE becomes apparent in the active sites of both subunits (Fig. 1 a). The positions and orientations of the L-ascorbates and the FTE molecules were determined with the help of Polder maps (Fig. 1a and b) (Liebschner et al., 2017) calculated using Phenix (Adams et al., 2010) v1.19.2-4158. After conventional refinement in Phenix, grouped occupancy refinement resulted in sub-stochiometric concentrations with occupancy values of the L-ascorbates varying from $\sim 60 \%$ in subunit $A$ to $\sim 70 \%$ in subunit B. 
bioRxiv preprint doi: https://doi.org/10.1101/2021.05.02.442358; this version posted May 20, 2021. The copyright holder for this preprint (which was not certified by peer review) is the author/funder, who has granted bioRxiv a license to display the preprint in perpetuity. It is made available under aCC-BY-NC-ND 4.0 International license.

11

210 Table S1. Data collection and refinement statistics.

\begin{tabular}{|c|c|c|}
\hline & \multicolumn{2}{|c|}{ SARS CoV-2 3CLpro } \\
\hline Beamline & \multicolumn{2}{|c|}{ APS 19-ID-D } \\
\hline Temperature & \multicolumn{2}{|c|}{$110 \mathrm{~K}$} \\
\hline Ligand & L-ascorbate (Vitamin C) & Dithiothreitol (DTT) \\
\hline Resolution $(\AA)$ & 2.3 & 2.3 \\
\hline Space group & $\mathrm{P} 2{ }_{1} 2_{1} 2_{1}$ & $\mathrm{C} 2$ \\
\hline Unit-cell parameters $\left(\AA{ }^{\circ},{ }^{\circ}\right)$ & $\begin{array}{l}\mathrm{a}=65.4 \AA \mathrm{d}=67.5 \AA \mathrm{c}= \\
157.5 \AA \\
\alpha=90^{\circ} \beta=90^{\circ} \gamma=90^{\circ}\end{array}$ & $\begin{array}{l}\mathrm{a}=113.39 \AA \mathrm{b}=53.4 \AA \mathrm{c}=44.7 \\
\AA \\
\alpha=90^{\circ} \beta=102.8^{\circ} \gamma=90^{\circ}\end{array}$ \\
\hline No of unique reflections & 30845 & 9426 \\
\hline Redundancy & $5.7(3.9)$ & $3.1(1.8)$ \\
\hline Completeness (\%) & $98.2(90.0)$ & 70.0 \\
\hline CC1/2@dmin & 45.2 & 47.6 \\
\hline $\mathrm{R}_{\text {merge }}(\%)$ & $20.4(145.6)$ & $7.3(122)$ \\
\hline $\begin{array}{l}\text { Model Building/ } \\
\text { Refinement }\end{array}$ & $\begin{array}{l}\text { Phenix 1.19.2-4158 } \\
\text { to } 2.3 \AA\end{array}$ & $\begin{array}{l}\text { refmac } 5.8 .0258 \\
\text { to } 2.2 \AA\end{array}$ \\
\hline $\mathrm{R}_{\text {crys }} / \mathrm{R}_{\text {free }}(\%)$ & $21.0 / 24.4$ & $19.1 / 26.3$ \\
\hline \# subunit/asymmetric unit & 2 & 1 \\
\hline \# residues/subunit & $303 / 310 *$ & 303 \\
\hline additional ligand & trifluoroethanol (FTE) & n.o. \\
\hline ligand occupancy & $\begin{array}{l}\text { Vitamin C: A } 0.66 ; \text { B } 0.67 * * \\
\text { FTE: A } 0.66 ; \text { B: } 0.68\end{array}$ & 0.85 \\
\hline \# water & 198 & 1184 \\
\hline R.m.s.d. bonds $(\AA) /$ angles $\left({ }^{\circ}\right)$ & $0.005 / 1.07$ & $0.007 / 0.949$ \\
\hline Coordinate Error $(\AA)$ & 0.25 & 0.18 \\
\hline
\end{tabular}

211 *in subunit B, electron density for seven additional C-terminal residues including that of two 212 histidines of the hexa-his tag can be observed.

$213 * *$ the difference electron density in any $\mathrm{F}^{\text {obs }}-\mathrm{F}^{\mathrm{calc}}$ difference map including the Polder map is 214 visually weaker in the active site of subunit A compared to that of subunit B.

215 n.o.: no additional ligand 
bioRxiv preprint doi: https://doi.org/10.1101/2021.05.02.442358; this version posted May 20, 2021. The copyright holder for this preprint (which was not certified by peer review) is the author/funder, who has granted bioRxiv a license to display the preprint in perpetuity. It is made available under aCC-BY-NC-ND 4.0 International license.

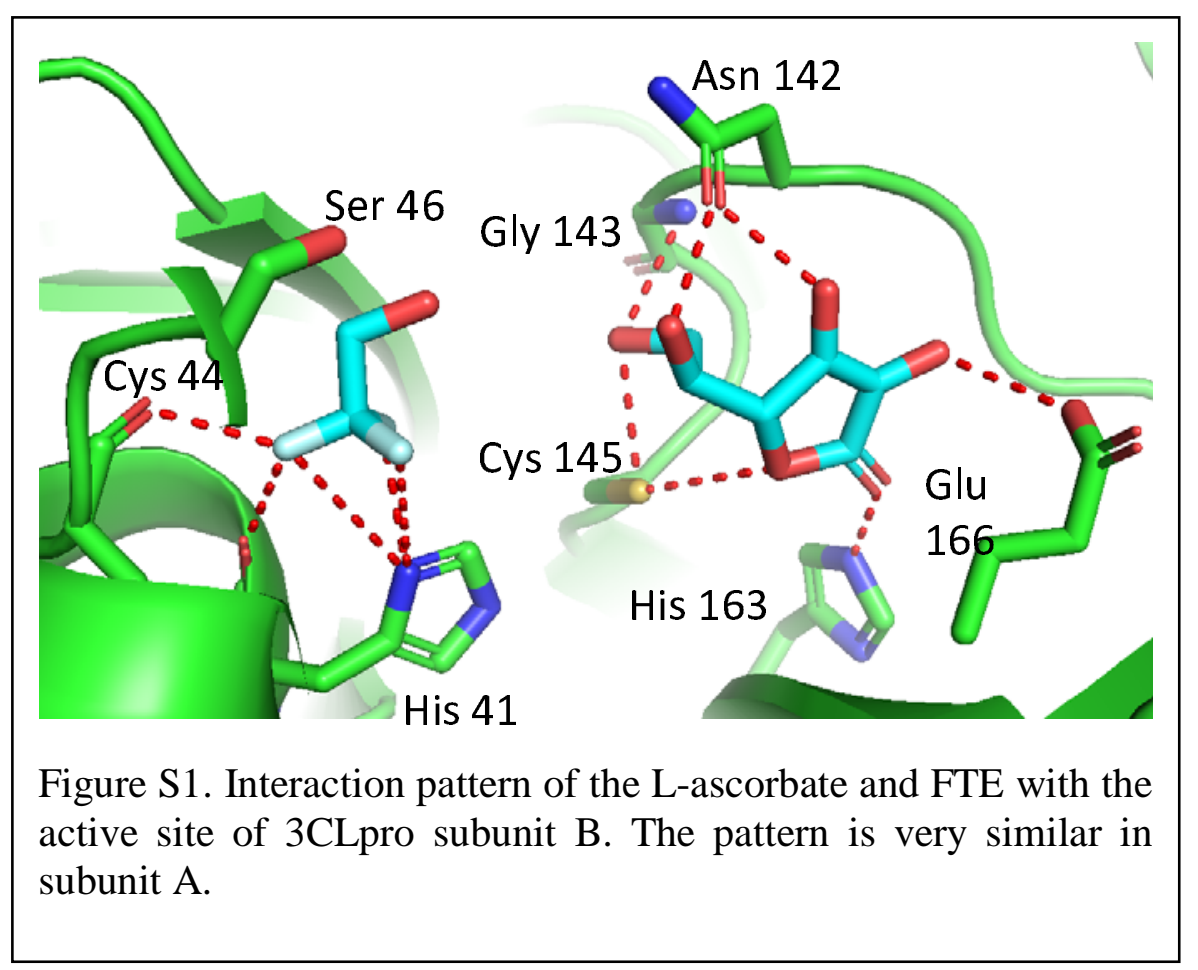




\section{References}

Adams, P. D., Afonine, P. V., Bunkoczi, G., Chen, V. B., Davis, I. W., Echols, N., Headd, J. J., Hung, L. W., Kapral, G. J., Grosse-Kunstleve, R. W., McCoy, A. J., Moriarty, N. W., Oeffner, R., Read, R. J., Richardson, D. C., Richardson, J. S., Terwilliger, T. C., \& Zwart, P. H. (2010). PHENIX: a comprehensive Python-based system for macromolecular structure solution. Acta Crystallogr D Biol Crystallogr, 66(Pt 2), 213221. https://doi.org/10.1107/S0907444909052925

Banic, S. (1975). Prevention of Rabies by Vitamin C. Nature, 258, 2.

Colunga Biancatelli, R. M. L., Berrill, M., \& Marik, P. E. (2020). The antiviral properties of vitamin C. Expert Rev Anti Infect Ther, 18(2), 99-101. https://doi.org/10.1080/14787210.2020.1706483

Cui, J., Li, F., \& Shi, Z. L. (2019). Origin and evolution of pathogenic coronaviruses. Nature Reviews Microbiology, 17(3), 181-192. https://doi.org/10.1038/s41579-018-0118-9

Douangamath, A., Fearon, D., Gehrtz, P., Krojer, T., Lukacik, P., Owen, C. D., Resnick, E., Strain-Damerell, C., Aimon, A., Abranyi-Balogh, P., Brandao-Neto, J., Carbery, A., Davison, G., Dias, A., Downes, T. D., Dunnett, L., Fairhead, M., Firth, J. D., Jones, S. P., Keeley, A., Keseru, G. M., Klein, H. F., Martin, M. P., Noble, M. E. M., O'Brien, P., Powell, A., Reddi, R. N., Skyner, R., Snee, M., Waring, M. J., Wild, C., London, N., von Delft, F., \& Walsh, M. A. (2020). Crystallographic and electrophilic fragment screening of the SARS-CoV-2 main protease. Nature Communications, 11(1), 5047. https://doi.org/10.1038/s41467-020-18709-w

Fowler Iii, A. A., Kim, C., Lepler, L., Malhotra, R., Debesa, O., Natarajan, R., Fisher, B. J., Syed, A., DeWilde, C., Priday, A., \& Kasirajan, V. (2017). Intravenous vitamin C as adjunctive therapy for enterovirus/rhinovirus induced acute respiratory distress syndrome. World J Crit Care Med, 6(1), 85-90. https://doi.org/10.5492/wjccm.v6.i1.85

Furuya, A., Uozaki, M., Yamasaki, H., Arakawa, T., Arita, M., \& Koyama, A. H. (2008). Antiviral effects of ascorbic and dehydroascorbic acids in vitro. Int J Mol Med, 22(4), 541-545. https://www.ncbi.nlm.nih.gov/pubmed/18813862

Gunther, S., Reinke, P. Y. A., Fernandez-Garcia, Y., Lieske, J., Lane, T. J., Ginn, H. M., Koua, F. H. M., Ehrt, C., Ewert, W., Oberthuer, D., Yefanov, O., Meier, S., Lorenzen, K., Krichel, B., Kopicki, J. D., Gelisio, L., Brehm, W., Dunkel, I., Seychell, B., Gieseler, H., Norton-Baker, B., Escudero-Perez, B., Domaracky, M., Saouane, S., Tolstikova, A., White, T. A., Hanle, A., Groessler, M., Fleckenstein, H., Trost, F., Galchenkova, M., Gevorkov, Y., Li, C., Awel, S., Peck, A., Barthelmess, M., Schluenzen, F., Lourdu Xavier, P., Werner, N., Andaleeb, H., Ullah, N., Falke, S., Srinivasan, V., Franca, B. A., Schwinzer, M., Brognaro, H., Rogers, C., Melo, D., Zaitseva-Doyle, J. J., Knoska, J., Pena-Murillo, G. E., Mashhour, A. R., Hennicke, V., Fischer, P., Hakanpaa, J., Meyer, J., Gribbon, P., Ellinger, B., Kuzikov, M., Wolf, M., Beccari, A. R., Bourenkov, G., von Stetten, D., Pompidor, G., Bento, I., Panneerselvam, S., Karpics, I., Schneider, T. R., Garcia-Alai, M. M., Niebling, S., Gunther, C., Schmidt, C., Schubert, R., Han, H., Boger, J., Monteiro, D. C. F., Zhang, L., Sun, X., Pletzer-Zelgert, J., Wollenhaupt, J., Feiler, C. G., Weiss, M. S., Schulz, E. C., Mehrabi, P., Karnicar, K., Usenik, A., Loboda, J., Tidow, H., Chari, A., Hilgenfeld, R., Uetrecht, C., Cox, R., Zaliani, A., Beck, T., Rarey, M., Gunther, S., Turk, D., Hinrichs, W., Chapman, H. N., Pearson, A. R., Betzel, C., \& 
Meents, A. (2021). X-ray screening identifies active site and allosteric inhibitors of SARS-CoV-2 main protease. Science. https://doi.org/10.1126/science.abf7945

Harakeh, S., Jariwalla, R. J., \& Pauling, L. (1990). Suppression of Human-ImmunodeficiencyVirus Replication by Ascorbate in Chronically and Acutely Infected-Cells. Proc Natl Acad Sci U S A, 87(18), 7245-7249. https://doi.org/DOI 10.1073/pnas.87.18.7245

Hilgenfeld, R. (2014). From SARS to MERS: crystallographic studies on coronaviral proteases enable antiviral drug design. Febs Journal, 281(18), 4085-4096. https://doi.org/10.1111/febs.12936

Hoog, S. S., Smith, W. W., Qiu, X., Janson, C. A., Hellmig, B., McQueney, M. S., O'Donnell, K., O'Shannessy, D., DiLella, A. G., Debouck, C., \& Abdel-Meguid, S. S. (1997). Active site cavity of herpesvirus proteases revealed by the crystal structure of herpes simplex virus protease/inhibitor complex. Biochemistry, 36(46), 14023-14029. https://doi.org/10.1021/bi9712697

Klein, M. (1945). The Mechanism of the Virucidal Action of Ascorbic Acid. Science, 101(2632), 587-589. https://doi.org/10.1126/science.101.2632.587

Kneller, D. W., Galanie, S., Phillips, G., O'Neill, H. M., Coates, L., \& Kovalevsky, A. (2020). Malleability of the SARS-CoV-2 3CL M(pro) Active-Site Cavity Facilitates Binding of Clinical Antivirals. $\quad$ Structure, 28(12), 1313-1320 e1313. https://doi.org/10.1016/j.str.2020.10.007

Liebschner, D., Afonine, P. V., Moriarty, N. W., Poon, B. K., Sobolev, O. V., Terwilliger, T. C., \& Adams, P. D. (2017). Polder maps: improving OMIT maps by excluding bulk solvent. $\begin{array}{llllll}\text { Acta Crystallogr } \quad D \quad \text { Struct } & \text { Biol, } & \text { 73(Pt } & \text { 2), }\end{array}$ https://doi.org/10.1107/S2059798316018210

Mescic Macan, A., Gazivoda Kraljevic, T., \& Raic-Malic, S. (2019). Therapeutic Perspective of Vitamin $\mathrm{C}$ and Its Derivatives. Antioxidants (Basel), 8(8). https://doi.org/10.3390/antiox8080247

Minor, W., Cymborowski, M., Otwinowski, Z., \& Chruszcz, M. (2006). HKL-3000: the integration of data reduction and structure solution - from diffraction images to an initial model in minutes. Acta Crystallographica Section D-Structural Biology, 62, 859-866. $<$ Go to ISI >://WOS:000239119800003

Murshudov, G. N., Skubak, P., Lebedev, A. A., Pannu, N. S., Steiner, R. A., Nicholls, R. A., Winn, M. D., Long, F., \& Vagin, A. A. (2011). REFMAC5 for the refinement of macromolecular crystal structures. Acta Crystallogr D Biol Crystallogr, 67(Pt 4), 355367. https://doi.org/10.1107/S0907444911001314

Oeffner, R. D., Bunkoczi, G., McCoy, A. J., \& Read, R. J. (2013). Improved estimates of coordinate error for molecular replacement. Acta Crystallographica Section D-Biological Crystallography, 69, 2209-2215. https://doi.org/Doi 10.1107/S0907444913023512

Pauling, L. (1970). Vitamin C and the Common Cold. W. H. Freeman and Company.

Ramajayam, R., Tan, K. P., \& Liang, P. H. (2011). Recent development of 3C and 3CL protease inhibitors for anti-coronavirus and anti-picornavirus drug discovery. Biochem Soc Trans, 39(5), 1371-1375. https://doi.org/10.1042/BST0391371

Sharma, A., \& Gupta, S. P. (2017). Fundamentals of Viruses and Their Proteases. Viral Proteases and Their Inhibitors, 1-24. https://doi.org/10.1016/B978-0-12-809712$\underline{0.00001-0}$

Thomas, S., Patel, D., Bittel, B., Wolski, K., Wang, Q., Kumar, A., Il'Giovine, Z. J., Mehra, R., McWilliams, C., Nissen, S. E., \& Desai, M. Y. (2021). Effect of High-Dose Zinc and 

Among Ambulatory Patients With SARS-CoV-2 Infection: The COVID A to Z Randomized Clinical Trial. JAMA Netw Open, 4(2), e210369. https://doi.org/10.1001/jamanetworkopen.2021.0369

Wu, F., Zhao, S., Yu, B., Chen, Y.-M., Wang, W., Song, Z.-G., Hu, Y., Tao, Z.-W., Tian, J.-H., Pei, Y.-Y., Yuan, M.-L., Zhang, Y.-L., Dai, F.-H., Liu, Y., Wang, Q.-M., Zheng, J.-J., Xu, L., Holmes, E. C., \& Zhang, Y.-Z. (2020). A new coronavirus associated with human respiratory disease in China. Nature, $479, \quad 4$. https://doi.org/https://doi.org/10.1038/s41586-020-2008-3

Zhang, L. L., Lin, D. Z., Kusov, Y., Nian, Y., Ma, Q. J., Wang, J., von Brunn, A., Leyssen, P., Lanko, K., Neyts, J., de Wilde, A., Snijder, E. J., Liu, H., \& Hilgenfeld, R. (2020). alphaKetoamides as Broad-Spectrum Inhibitors of Coronavirus and Enterovirus Replication: Structure-Based Design, Synthesis, and Activity Assessment. Journal of Medicinal Chemistry, 63(9), 4562-4578. <Go to ISI>://WOS:000535279800012

Zhang, L. L., Lin, D. Z., Sun, X. Y. Y., Curth, U., Drosten, C., Sauerhering, L., Becker, S., Rox, K., \& Hilgenfeld, R. (2020). Crystal structure of SARS-CoV-2 main protease provides a basis for design of improved alpha-ketoamide inhibitors. Science, 368(6489), 409-+. <Go to ISI $>$ ://WOS:000528513300041

Zhao, B., Ling, Y., Li, J., Peng, Y. B., Huang, J., Wang, Y. H., Qu, H. P., Gao, Y., Li, Y. C., Hu, B. J., Lu, S. H., Lu, H. Z., Zhang, W. H., \& Mao, E. Q. (2021). Beneficial aspects of high dose intravenous vitamin $\mathrm{C}$ on patients with COVID-19 pneumonia in severe condition: a retrospective case series study. Annals of Palliative Medicine, 10(2), 1599-+. https://doi.org/10.21037/apm-20-1387 